\title{
Factors to affect inbred beet plants while developing material for linear selection
}

\author{
M.I. Fedorova, E.G. Kozar, S.A. Vetrova @, V.A. Zayachkovskyi, V.A. Stepanov \\ Federal Scientific Vegetable Center, VNIISSOK, Odintsovo region, Moscow district, Russia \\ هe-mail: lana-k2201@rambler.ru
}

Considering its capacities, the generative system of Beta vulgaris L. is regarded as highly productive. While inbreeding, the reproductive potential of cross-pollinated beet plants with gametophytic self-incompatibility (SI) changes significantly and is determined by a joint effect of multiple factors including the level of inbred depression. In the present study, original data have been obtained revealing relationships between inbred beet seed productivity, its self-incompatibility and microgametophyte parameters, which is crucial for developing and maintaining constant fertile beet lines. It has been discovered that inbred depression increases the number of sterile microgametes and anomalous pollen grains, reduces pollen fertility and the length of pollen tubes. As a result, the seed yield in inbred beet progeny, including SI ones, reduces significantly just after the third inbreeding. At the same time, highly productive inbred beet is characterized by a lower rate of pollen tube growth in vitro. In inbred plants, there is no close relationship between pollen viability and seed productivity, because the elimination of germinated male gametes and degeneration of seed embryos may go over the entire period of fertilization starting its progamic phase. The SI plants have more degenerating embryos than self-fertile ones, but seed vessel outgrowth in the seeds with abortive embryos makes them morphologically similar to fertile seeds. For that reason, when assessing inbred beet plants based on their self-incompatibility/self-fertility, one should consider the qualitative characteristics of the seeds. Using the method of recurrent selection based on such factors as seed productivity, pollen tube length and field germination rate increase the output of plant forms with a potentially high self-compatibility in their progeny. To support such genotypes in the progeny, one has to, starting from the third inbreeding, perform sib crossing to reduce the negative effect of inbred depression and self-incompatibility.

Key words: beetroot; inbreeding; inbreeding depression; seed productivity; incompatibility; microgametophyte; pollen germination; pollen tubes.

For citation: Fedorova M.I., Kozar E.G., Vetrova S.A., Zayachkovskyi V.A., Stepanov V.A. Factors to affect inbred beet plants while developing material for linear selection. Vavilovskii Zhurnal Genetiki i Selektsii=Vavilov Journal of Genetics and Breeding. 2019;23(4):439-447. DOI 10.18699/VJ19.512

\section{Факторы, влияющие на репродуктивную способность инбредных растений свеклы столовой при создании линейного материала для селекции}

\author{
М.И. Федорова, Е.Г. Козарь, С.А. Ветрова $\otimes$ В.А. Заячковский, В.А. Степанов
}

Федеральный научный центр овощеводства, пос. ВНИИССОК, Одинцовский район, Московская область, Россия هe-mail: lana-k2201@rambler.ru

\begin{abstract}
Генеративная система Beta vulgaris L. по своему устройству и возможностям относится к высоковоспроизводящей. При самоопылении репродуктивный потенциал перекрестноопыляемых растений свеклы столовой, имеющих гаметофитный тип самонесовместимости, существенно изменяется и определяется совокупным действием разных факторов, в том числе и уровнем инбредной депрессии. Впервые на культуре свеклы столовой получены оригинальные данные о характере взаимосвязей семенной продуктивности инбредных растений с функциональными параметрами микрогаметофита и степенью самонесовместимости, что имеет важное значение при создании и поддержании константных фертильных линий. Установлено, что в результате инбредной депрессии увеличивается число стерильных микрогамет и пыльцевых зерен с аномальным развитием; снижается фертильность пыльцы и длина пыльцевых трубок; семенная продуктивность в потомствах инбредных растений, в том числе склонных к самоопылению, резко снижается уже после третьего инбридинга. При этом для высокопродуктивных инбредных растений свеклы столовой характерна меньшая скорость роста пыльцевых трубок в условиях in vitro. Между уровнем жизнеспособности пыльцы и семенной продуктивностью инбредных растений тесная взаимосвязь отсутствует ввиду того, что элиминация проросших мужских гамет и дегенерация зародышей семян могут происходить на всем протяжении прогамной и последующих фаз оплодотворения.
\end{abstract}




\begin{abstract}
Дегенерирующих зародышей у самонесовместимых форм намного больше, чем у самофертильных, но в результате разрастания околоплодника у семян с недоразвитыми зародышами наблюдается морфологическое сходство со всхожими семенами. Поэтому при оценке инбредных растений свеклы столовой по признаку «самонесовместимость/самофертильность» следует учитывать качественные характеристики семян. Использование метода рекуррентной селекции по признакам «семенная продуктивность», «длина пыльцевых трубок» и «полевая всхожесть» повышает выход форм с потенциально высокой самосовместимостью в потомстве. Для поддержания выделенных в инбредных потомствах ценных генотипов необходимо начиная с третьего инбридинга проводить сибсовые скрещивания, что позволяет снизить негативное влияние инбредной депрессии и самонесовместимости.

Ключевые слова: свекла столовая; инбридинг; инбредная депрессия; семенная продуктивность; самонесовместимость; микрогаметофит; жизнеспособность; пыльцевая трубка.
\end{abstract}

\section{Introduction}

Table beet (Beta vulgaris L.) is one of the most common root vegetables and is cultivated all over the world. The presence of heterocyclic nitrogen-containing betacyanin pigments such as betanin and betaine in its roots makes this culture unique and essential in terms of human nutrition (Krasochkin, 1971; Pialetti, 1976; Mabry, 1980; Escribano et al., 1998; Tesoriere et al., 2004; Lapin et al., 2007; Sleptsov et al., 2015).

Table beet outperforms other root vegetables in productivity due to the structure of the generative system and its crosspollination potential. Table beet is clearly identified as a crosspollinating plant with the gametophytic self-incompatibility system (Owen, 1942; Maletsky et al., 1970). However, in addition to pollinating by pollen grains from other plants (xenogamy), the plants can be pollinated by pollen grains from other flowers of the same plant (geitonogamy) and from the same flowers (autogamy) (Zhuzhzhalova et al., 2007).

A wide variety of foreign and domestic breeds of table beet is available in the market, however, the producers prefer $\mathrm{F}_{1}$ hybrids, which are more unified, flexible, and therefore better suited for production. The cultivation technology minimizes the manual labor involved, which in turn reduces money and time costs (Burenin, Pivovarov, 1998; Fedorova, Burenin, 2010). The heterosis effect reaches its peak, when the progeny hybridity is at its maximum that is effectively achieved by various genetic reproductive systems, particularly cytoplasmic male sterility (CMS) potentially presenting in each cross-pollinated population (Maletsky, 2010).

Selection for heterosis includes several consecutive stages as follows: studying a variety of original material preferably among monogerm samples, obtaining inbred progenies, selecting valuable biotypes and using them as the base for obtaining fertile (mf) and sterile (ms) lines with high combining ability, obtaining $\mathrm{F}_{1}$ hybrids with the set of agriculturally valuable attributes. Obtaining homozygous lines via inbreeding is considered a critical element of a formative process facilitating the identification of valuable biotypes with recessive alleles, when dealing with complex heterogeneous populations of cross-pollinating cultures. Self-pollination makes it possible to decompose heterogeneous populations into series of homozygous lines of target genes, which, in addition to inbreeding depression, possess valuable attributes (Vavilov, 1935).

At the early stages of CMS-based hybrid creation, it is not only genetic and breeding aspects that present problems for breeders, but seed production as well. As opposed to cross-pollinating variety populations, whose genetic stability is ensured by cross-pollination within the intrabreeding population, self-fertilization ability is required for obtaining and maintaining the lines (Balkov, 1978; Fedorova, Stepanov, 2005; Zhuzhzhalova, 2010; Burenin, 2015).

Seed productivity of inbred beet progenies is highly variable as a result of various genes, including the self-incompatibility gene, as well as inbreeding depression. Self-incompatibility during self-pollination occurs, when pollen grains and the pistil have matching S-genes. Depending on the action period of genes and localization of their byproducts, two types of homomorphic self-incompatibility are defined for the eudicot group, namely sporophytic and gametophytic. However, some species may demonstrate a combination of individual attributes of these systems (Zhuzhzhalova et al., 2007).

Growth inhibitor (protein complex) in the SSI system is activated at the stigma, when pollen grains and the pistil have matching monomers, which inhibit pollen germination (Lewis, Crowe, 1958; Knox, Heslop-Harrison, 1970; Foote et al., 1994; Chantha et al., 2013). According to the recent data, the GSI system in a number of species is based on recognizing specific ribonuclease (S-RNase) in the diploid tissue of the pistil splitting the stored rRNA of its own pollen grains (pollen tube growth is terminated) and S-related F-box proteins of the male haploid capable of inactivating a subset of S-RNase alleles, except for their allele relative (Entani et al., 2003; Yamane et al., 2003; Kubo et al., 2010; Ramanauskas, Igić, 2017; Chen et al., 2018). The SI system in beet plants is controlled by four S-loci, while having a gametophytic incompatibility type, but it still remains understudied at the molecular level (Lundqvist et al., 1973; Zhuzhzhalova, 2010).

While the percentage of self-incompatible plants in sugar beet populations may reach $50 \%$ or more, they also include self-compatible plants, whose pollen grains germinate massively as a result of self-pollination (Magassy, 1965; Korneeva, Golichenko, 1989; Logvinov et al., 1993; Darmency et al., 2009). The plants setting up to 50 seeds are considered self-sterile or self-incompatible (SI), 50 to 100 seeds prone to self-fertilization (PSF), 100 seeds and above self-compatible or self-fertile (SF) (Balkov, 1978).

It is shown that compatibility attribute and the percentage of SF plants in inbred sugar beet progenies may become fixated; their seed productivity in a series of generations may increase, though it is not a universally observed phenomenon (Konovalov, Maletsky, 1990; Zhuzhzhalova, 2010; Oshevnev, Gribanova, 2010). Consecutive self-pollination reduces pollen grain fertility in inbred progenies, which in turn depends on the 
genotype of the inbred plants (Maletsky, 1995; Zayachkovsky et al., 1999; Korneeva, Vlasyuk, 2003; Darmency et al., 2009). In addition, pollen grain fertility in self-compatible plants following single to triple inbreeding decreases significantly slower than in inbred progenies of self-incompatible plants, demonstrating a sharp increase in pollen grain development anomalies leading to microgametophytic sterilization during gametogenesis.

The further inbred reproduction leads to lower pollen fertility in SF-forms, which in case of deep inbreeding (up to $\mathrm{I}_{10}$ ) may fall down to $20 \%$ of the initial value (Konovalov, Maletsky, 1990; Fedorova, Stepanov, 2005). As a result, similarly to SI-forms, valuable genotypes may be lost in SF-forms, which occurs most often in the process of creating fertile B-lines responsible for CMS fixation (Lyalko et al., 1997; Zhuzhzhalova, 2010). Thus, when dealing with inbred table beet progenies, the primary goal is to search for the mfforms not only prone to self-pollination but also capable of overcoming the inbreeding depression. At the same time, it is important that seed productivity threshold under inbreeding depression is not neglected.

The goal of the presented research was to study the relations between seed productivity and functional parameters of male gametophytes in table beet plants during inbreeding in order to develop constant lines and ensure their preservation and reproduction.

\section{Materials and methods}

The research was performed at the facilities of the Federal Scientific Vegetable Center (VNIISSOK) from 2007 to 2017 with seed plants of various inbred beet progenies obtained using Nezhnost variety population. The breed was derived via free cross-pollination of foreign hybrids with cylindrical root shape followed by individual selection, inbreeding, and sister crossing. It was the very first inbred generation of this population that included fully fertile and partially sterile plants with the CMS attribute manifested to various degrees (i. e. different ratios of sterile and fertile anthers at flower, inflorescence, or branch scales). CMS in table beet plants is manifested phenotypically as a marker coloring of ms-anthers with individual parts of plants showing a wide spectrum of maroon tints from pink to brown (Fedorova et al., 2011).

The plants were grown in a protected ground in unheated hangar- or block-type hothouses under conditions of springsummer crop rotation with natural lighting using one-year (stecklings) or two-year development cycles. Enforced selfpollination of the seed plants and sib crossings were performed using two types of pollination bags, namely parchment for isolation of individual branches of the plant, and calico for individual plants and groups of plants. To overcome the inbreeding depression, sib (sister) group crossings (a group of at least three plants under the common pollination cover) were used starting with the third inbreeding.

Biometric and functional microgametophytic parameters in fertile and partially sterile inbred plants were studied in vitro using the technique developed at VNIISSOK (Kozar et al., 2017). The sample size for triple analysis calculations and measurements was 300-500 pollen grains. A microphotographic study was carried out using a Micros microscope with DCM 300 digital camera and Canon A560 photographic system with magnifications $\times 10 \times 10$ and $\times 20 \times 10$. Pollen grains from various fractions were calculated and their parameters measured using the Scope Photo software. The viability of the microgametophytic population was estimated as the percentage of germinated pollen grains in the total number of grains in the sample analyzed. Polymorphism was assessed based on the percent ratio between pollen grain fractions, which included fertile, germinated (viable), anomalous, and sterile grains.

The reproductive ability and self-compatibility of inbred plants were assessed based on seed productivity (SP) and field germination rate. Genotypes with seed productivities of 0 to $1 \mathrm{~g}$ were classified as SI regardless of the germination rate, as were plants with higher productivity with germination rates below $20 \%$; a PSF group included the plants with seed productivities from 1 to $4 \mathrm{~g}$; and a SF group - the plants with seed productivities above $4 \mathrm{~g}$ with germination rates above $20 \%$.

Express tests of seed quality were performed by means of microfocus radiography using the PRDU-02 and RM-1 systems. The internal structure of seeds was analyzed using the methods described in Technique of Radiographic Studies for Agriculture (Arkhipov et al., 2001) and Crop Science and Radiographic Analysis of Seed Quality in Vegetable Cultures (Musaev et al., 2012). Mathematical processing of the results was implemented using the Microsoft Excel statistical analysis tools.

\section{Results}

Comparative analysis of the obtained SP data showed that inbred progenies $\left(\mathrm{I}_{1}-\mathrm{I}_{3}\right)$ included both low productive plants and the ones setting a sufficient number of seeds, and the ratios between them varied significantly within the inbred progeny on the whole and for each sample in particular. The percentage of SI plants in inbred populations showed steady increase of as much as three times on average in each subsequent inbred generation. As a result, the percentage of plants capable of self-pollination in the third inbred populations was $33 \%$, whereas the same value for the first inbred generation was $90 \%$, with $56 \%$ of plants having seed productivities of over $5 \mathrm{~g}$. Average seed productivity parameters of the inbred plants from different generations remained approximately the same: $\mathrm{I}_{1}-11.2 ; \mathrm{I}_{2}-11.9 ; \mathrm{I}_{3}-10.4 \mathrm{~g} /$ plant (Suppl. material 1$)^{1}$.

The effect of consecutive self-pollination on the variability of microgametophytic parameters was studied and the relation of these parameters with the reproductive ability of the inbred beet plants was analyzed in breed sample 274, whose population was characterized by the lowest amount of SI genotypes (7\%). Here, the plants selected for further inbreeding were primarily the ones prone to self-fertilization, which were typically present in all inbred progenies. The structure of their inbred progenies included fully SI genotypes $(\mathrm{SP}=0 \mathrm{~g})$, whose percentage increased gradually with inbreeding depth $\left(\mathrm{I}_{1} \rightarrow \mathrm{I}_{5}\right)$ and reached $21 \%$ in the fifth inbred generation (Table 1).

According to the average values, seed productivity in the plants capable of self-pollination remained high up to the third inbred generation. Further inbreeding dramatically reduced

\footnotetext{
${ }^{1}$ Supplementary Materials 1-3 are available in the online version of the paper: http://www.bionet.nsc.ru/vogis/download/pict-2019-23/appx8.pdf
} 
Table 1. Seed yield and pollen fertility for different inbred beet progenies No. 274

\begin{tabular}{|c|c|c|c|c|c|c|c|c|}
\hline \multirow[t]{2}{*}{ Inbreeding } & \multirow[t]{2}{*}{$\begin{array}{l}\text { Seed yield, g/plant } \\
\text { (average) }\end{array}$} & \multicolumn{3}{|c|}{ Plants (\%) with seed productivity } & \multirow[t]{2}{*}{$\begin{array}{l}\text { Pollen fertility, \% } \\
\text { (average) }\end{array}$} & \multicolumn{3}{|c|}{$\begin{array}{l}\text { Portions of plants (\%) with different } \\
\text { levels of pollen fertility }\end{array}$} \\
\hline & & $0 \mathrm{~g}$ & $0.1-4.0 \mathrm{~g}$ & $>4 \mathrm{~g}$ & & $<70 \%$ & $70-90 \%$ & $>90 \%$ \\
\hline $\mathrm{I}_{1}$ & 14.5 & 7 & 33 & 60 & 92 & 1 & 26 & 73 \\
\hline$I_{2}$ & 13.4 & 8 & 42 & 50 & 84 & 3 & 33 & 64 \\
\hline $\mathrm{I}_{3}$ & 9.3 & 14 & 55 & 31 & 80 & 10 & 61 & 29 \\
\hline $\mathrm{I}_{4}$ & 2.5 & 16 & 64 & 20 & 82 & 8 & 44 & 48 \\
\hline $\mathrm{I}_{5}$ & 6.1 & 21 & 49 & 30 & 76 & 20 & 35 & 45 \\
\hline $\mathrm{HCP}_{05}$ & 4.2 & & & & 4 & & & \\
\hline
\end{tabular}
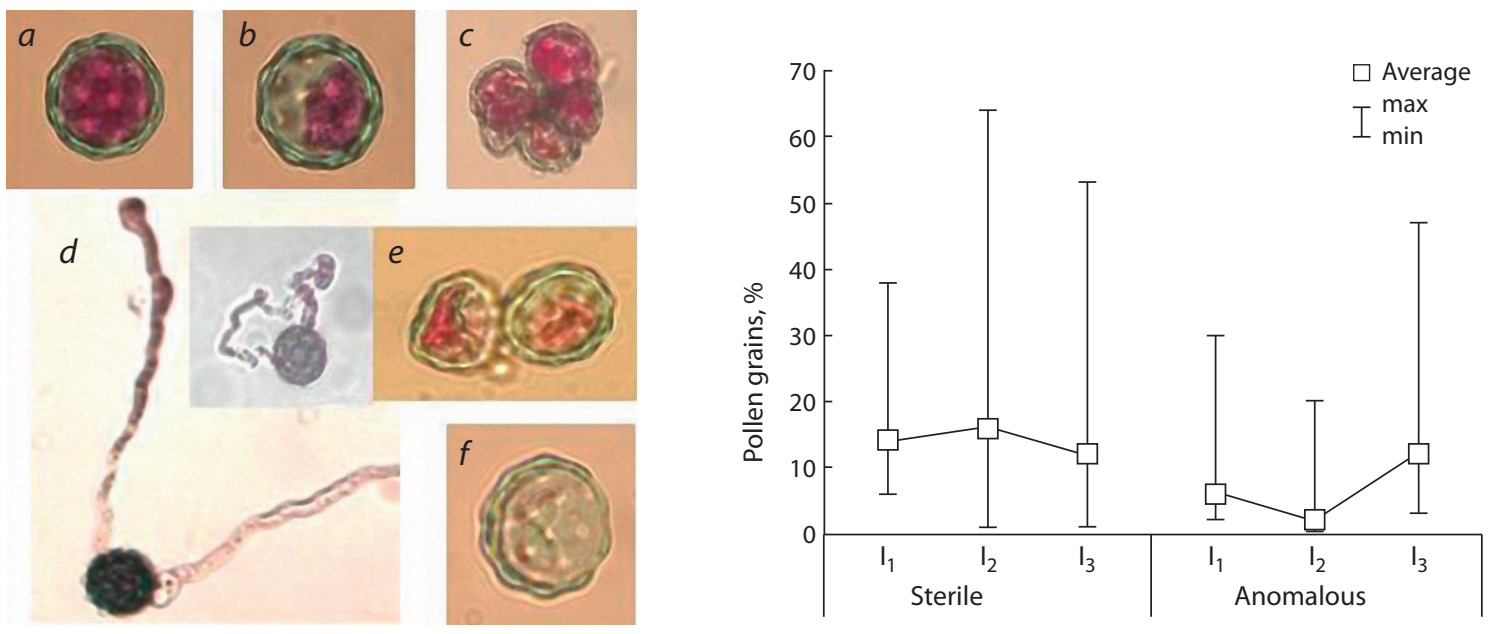

Fig. 1. Sterile and anomalous microgametes in the pollen populations of different inbred beet plants: $a$, fertile pollen grains; $b-e$, anomalous pollen grains; $f$, sterile pollen grains.

seed productivity in plants, including the SF group, which then only accounted for 20-30\%. It may be explained by the effect of growing inbreeding depression on the development of reproductive organs. As a result, pollen grain fertility decreased due to the increasing number of sterile microgametes and anomalous pollen grains (deformation, detachment of contents from the shells, germination of several pollen tubes, etc.); the number of these plants doubled in the fifth inbred progeny (Table 1, Fig. 1).

Inbreeding depression also affected functional parameters of pollen grains, primarily in vitro pollen tube growth. The average pollen tube length in plants from the fourth-fifth inbred generations after three-hour germination turned out to be twice as short as in plants from the third inbred generation. In addition, consecutive inbreeding progenies starting from the second inbred generation showed a gradual decrease in the variability of this attribute and an increase in the percentage of plants with low pollen tube growth rate $\left(L_{\mathrm{pt}}<200\right.$ per unit) (Table 2).

In addition, plants from various inbred generations manifested differences, although less significant, in fertile pollen grain viability, which generally fell within a wide interval (0-55\%). However, no specific regularity was observed to describe variations in population structure regarding ratios of genotypes with different viability values. For instance, genotypes with average pollen grain germination rate (viability of $10-30 \%$ ) prevailed in the third inbred generation; low viability $(<10 \%)$ prevailed in the fourth inbred generation, but most plants from the fifth inbred generation showed the ability of pollen grains to germinate in vitro (with viability of over $30 \%$ ). It possibly has to do with phenotypic variability, which is to a significant degree determined by the effect of agricultural climatic cultivation conditions on simultaneous maturation and pollen grain maturity. In other words, the data obtained indicate that the inbreeding depression of microgametophytic development combined with selfincompatibility affects the reproductive ability in inbred plants.

Relation between seed productivity and microgametophytic parameters in beet plants with different inbreeding levels. Structural analysis of individual groups of inbred mf-plants with different SP values showed a certain relation between microgametophytic parameters and seed productivity up to the third inbreeding. For example, in the third inbred generation plants with low fertility $(<70 \%)$ and viability $(<10 \%)$ were only encountered in the low productive group 
Table 2. Variability and structure of inbred beet progenies considering the viability and pollen tube length of the fertile pollen of seed plants

\begin{tabular}{|c|c|c|c|c|c|c|c|c|c|c|}
\hline \multirow[t]{2}{*}{$\begin{array}{l}\text { Inbred } \\
\text { progeny }\end{array}$} & \multicolumn{2}{|c|}{ Viability, \% } & \multicolumn{3}{|c|}{ Plants with survival capacity, \% } & \multicolumn{2}{|c|}{$\begin{array}{l}\text { Pollen tube length, } \\
\text { rel. units }\end{array}$} & \multicolumn{3}{|c|}{$\begin{array}{l}\text { Plants (\%) with } \\
L_{\mathrm{pt}} \text { (rel. units) }\end{array}$} \\
\hline & average & $\min -\max$ & $<10$ & $10-30$ & $>30$ & average & $\min -\max$ & $<200$ & $200-300$ & $>300$ \\
\hline $\mathrm{I}_{3}$ & 20 & $1-44$ & 23 & 48 & 29 & 446 & $78-790$ & 19 & 14 & 67 \\
\hline $\mathrm{I}_{4}$ & 17 & $0-52$ & 44 & 32 & 24 & 263 & $94-540$ & 24 & 44 & 32 \\
\hline$I_{5}$ & 25 & $0-55$ & 20 & 20 & 60 & 257 & $110-430$ & 28 & 30 & 42 \\
\hline $\mathrm{HCP}_{05}$ & 9 & & & & & 84 & & & & \\
\hline
\end{tabular}
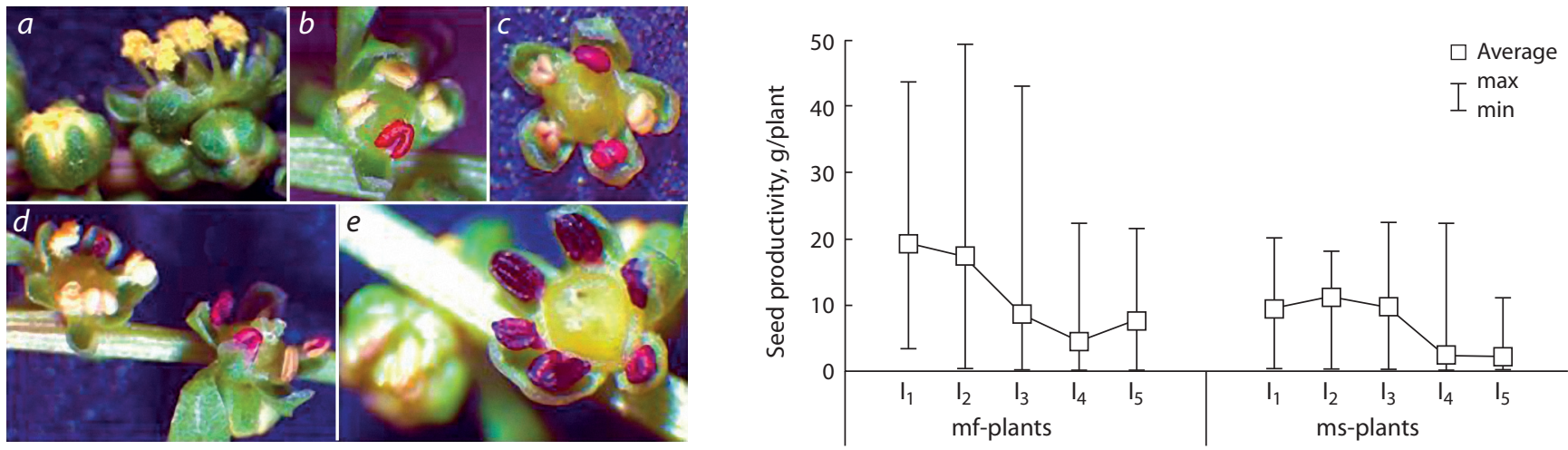

Fig. 2. Variability of the seed productivity in fertile $(a)$ and partially sterile $(b, c$ - individual sterile anthers at flower; $d$, $e$ - ms-flowers and branches on a plant) plants in different inbred beet progenies.

(SP $<1 \mathrm{~g})$; in the fourth inbred generation these genotypes were found in the group with average SP (1-4 g), and in the fifth inbred generation in the high productivity group ( $\mathrm{SP}>4 \mathrm{~g}$ ) as well; in addition, the percentage of inbred plants with low pollen viability almost leveled off in all groups at $20-30 \%$ of the total number of plants in each respective group. Inbreeding depression of pollen tube growth manifested itself in some plants as early as the second inbred generation, and percentages of these genotypes in groups with low and average SP reached 25 and $20 \%$ respectively in the third inbreeding progeny (Suppl. material 2).

From the breeding perspective, the plants from all inbred progenies of high productive groups with high fertility and pollen grain viability of over $30 \%$ are of interest. The percentage of plants with high pollen tube growth rates $\left(L_{\mathrm{pt}}>300 \mu \mathrm{m} /\right.$ hour $)$ in this group decreased with higher inbreeding levels and reached $20 \%$ in the fifth inbreeding progeny, whereas this value was about $60 \%$ in the low productive group (see Suppl. material 2).

A decrease in seed productivity and its variation range in the plants prone to self-pollination show similar patterns in mf-plants and partially sterile ms-plants (Fig. 2). At the same time, the following differences are observed: average seed productivity of ms-plants in case of self-pollination is significantly lower than in fully fertile plants, whose variation range is almost twice as wide in the first three inbreeding progenies. Sharp decrease in seed productivity was observed in mf-plants from the third inbred generation and in ms-plants from the fourth inbred generation with prevalence of SI forms.
Thus, the observed growth in the number of SI plants in the fourth-fifth inbred generations is primarily associated with the presence of partially sterile plants in progenies, which are to be removed starting from the third inbreeding. It is especially important for developing a mf-line responsible for CMS fixation (see Table 1).

In other words, the research showed that reproductive potential of inbred plants subjected to multiple self-pollinations is to a greater extent determined by the degree of self-compatibility since both low and high seed productivities were observed in plants with different CMS manifestations and functional parameter combinations of pollen grains. The further analysis confirmed the absence of constant correlation between the microgametophytic attributes and seed productivity of individual plants from each inbred progeny. However, the mf-plants prone to self-fertilization demonstrated a stable trend in all progenies, namely that of a lower in vitro pollen tube growth rates in productive genotypes (Fig. 3,a). A similar relation was also observed in individual inbred families, especially in the ones with widely varying seed productivity. For example, the correlation coefficient between pollen tube length and seed productivity in plants from the third inbred generation was $r=-0.64$ for inbred families No. 274-2 and 274-4, while for other families it varied from $r=-0.19$ to $r=-0.59$.

The relation between pollen grain viability and seed productivity of inbred plants is ambiguous. A positive correlation between these parameters ( $r=0.40 \ldots 0.49)$ is only observed in generations with high inbreeding levels $\mathrm{I}_{3-5}$ for the mf-plants prone to self-fertilization. Moreover, pollen grain viability 


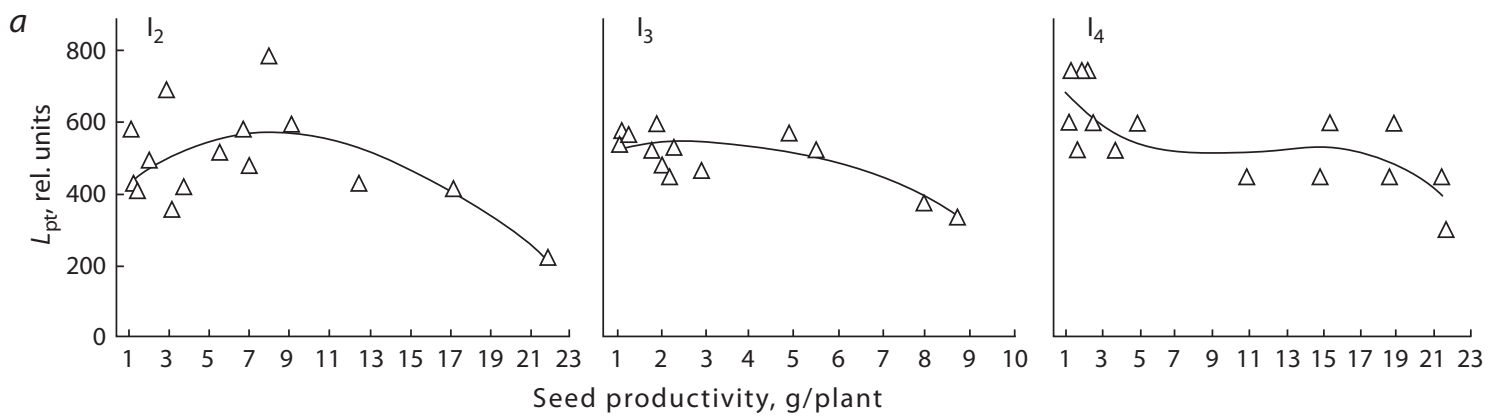

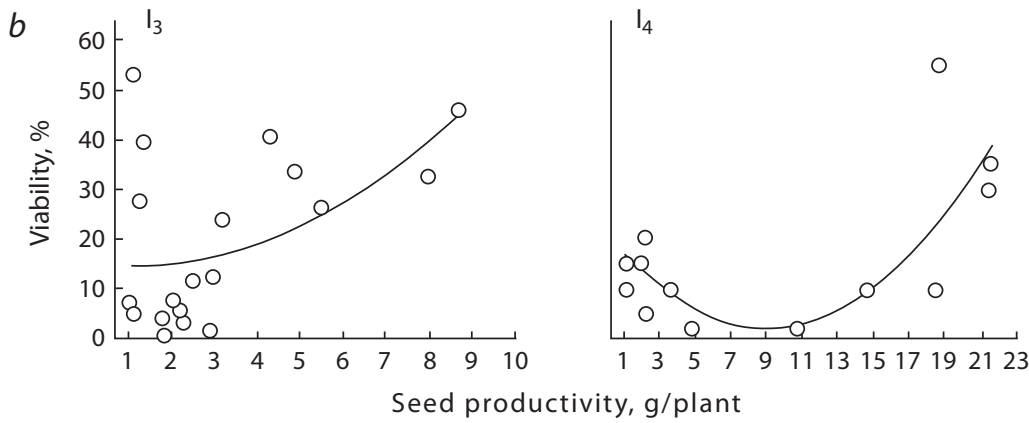

Fig. 3. Relation between seed productivity and pollen tune length ( $a$ ), and the pollen-grain viability $(b)$ of inbred mf-beet SI plants. affected the number of fertile seeds $(r=0.53 \ldots 0.56)$ with normal embryos capable of producing adult plants to form roots only in some of these progenies (Fig. $3, b$ ). Thus, in case of comparable pollen grain viabilities, the fertilization outcomes may still be different for inbred plants with varying degrees of the SI attribute manifestation.

It is caused by the fact that male gamete elimination occurs throughout the whole duration of the progamic phase, and the more incompatible the plant, the earlier the progamic phase anomalies are observed and the more pronounced they are. The absence of fertilization is the main cause of embryo deaths. However, embryo development may continue up until the sphere stage even without fertilization, but as soon as the central cell does not function properly and does not form an endosperm, the embryo dies. A study of subsequent embryogenesis stages during seed formation has shown that embryo and seed degeneration in case of self-pollination of beet plants is observed at various development stages, while the number of degenerating embryos is much higher in self-sterile forms, than in self-fertile ones. The seeds with underdeveloped embryos bear superficial resemblance to fertile seeds as a result of seed vessel outgrowth (Zhuzhzhalova et al., 2007).

In this context, the fertile seed weight per plant calculated as $M_{\mathrm{g}}=M_{\mathrm{o}} \times \mathrm{B} / 100$, where $M_{\mathrm{o}}$ is the total seed weight (g) per plant, and B is the field germination rate (\%), should be considered a more adequate criterion for ranking plants by self-incompatibility/fertility. Genotypes with $M_{\mathrm{g}}<0.5 \mathrm{~g} /$ plant are attributed to the SI group; the ones with $0.5 \leq M<1.0 \mathrm{~g} / \mathrm{plant}$ to the PSF group; and the ones with $M_{\mathrm{g}} \geq 1.0 \mathrm{~g} / \mathrm{plant}$ to the SF group (Fig. 4, a). It can be seen from the figure that both SI and SF groups include plants with comparable total seed productivities, but field germination rate and therefore fertile seed weight is higher in SF plants with low productivity than in SI plants.

Microfocus radiography, which makes it possible to identify the presence of a developed embryo in each seed even before germination, may be used to obtain a preliminary estimate of the manifestation degree of self-incompatibility in the given inbred beet progeny (Musaev et al., 2017a, b). It can be seen from the radiographic image that internal areas in most seeds from inbred progenies 274/5-6-1-9a and 274/2-3-15-4a were either fully shaded or only show rudiments of non-viable embryos (light areas), which did not germinate when sown (Fig. 4, $b$ ).

Taking seed productivity and field germination rates into account, these progenies were attributed to the SI group (see Fig. 4, a); the progenies of families 274/5-5-3-3a and 274/55-3-1a were attributed to the SF group, since despite low total seed productivity (about $2 \mathrm{~g}$ ), they were characterized by high filed germination rates (76 and $53 \%$ respectively), which is also confirmed by radiography results. In addition, radiographic images may be used to identify individual plants and progenies as polygerm or monogerm, which is important for choosing a breeding type (see Fig. $4, b$ ).

Sib crossing for preserving valuable inbred lines. Sib crossings within individual progenies of mf-forms reduce the inbreeding depression effect on microgametophytic functional parameters. For instance, pollen grain viability in plants from progenies of the initial inbred form 274-5-6-1 increased by 4-32\% depending on the progeny (apart from 274-5-6-111a). Pollen tube growth rate also increased in most samples, the tube length being 1.2-2 times as high as in inbred plants. Progenies of 274-5-6-1-11a and 274-5-6-1-12a were the only 

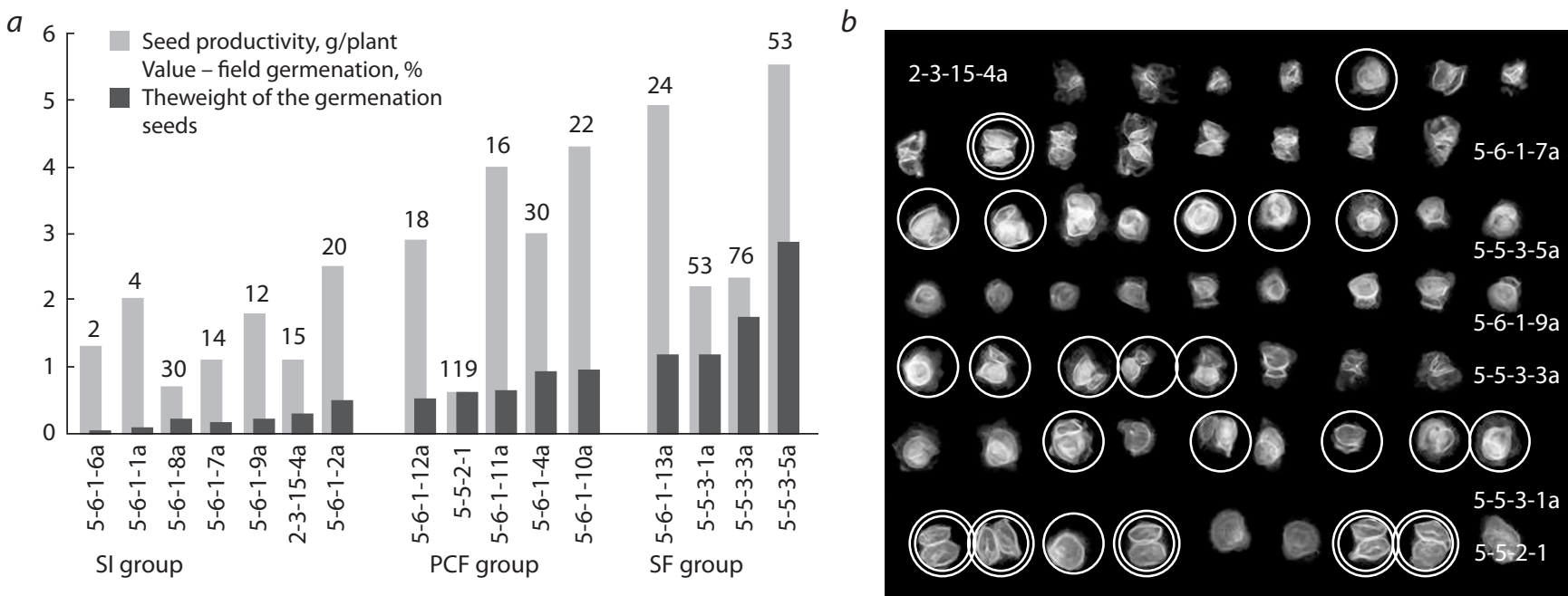

Fig. 4. Fertile-seed mass distribution for inbred beet progenies ( $a$ ), and X-ray image fragments of the seeds (b).

O - Fertile one-seeded fruit; (1) - Fertile two-seeded fruit.

exceptions, where the value considered varied within the experimental error (Suppl. material 3).

A close relation was observed between pollen grain viability and pollen tube length in plants from inbred and sib progenies ( $r=0.88$ and $r=0.64$ respectively), as opposed to seed productivity since its increase during sib crossings was caused not only by reduced inbreeding depression but the absence of negative self-incompatibility effects as well. Nevertheless, an inverse relation was observed between tube lengths and seed productivities $(r=-0.47)$, similarly to inbred progenies.

In most progenies resulting from sib crossings, productivity either showed statistically significant increases (1.4-6.6 times and more) or remained at the level typical for inbred plants. The quality of the obtained seeds improved significantly, and their field germination rates per seed unit (glome) were over $40 \%$ in most progenies. Here, $42 \%$ of sib progenies had polygerm glomes (with the field germination rate of over $100 \%$ ), whereas the percentage of polygerm samples among inbred progenies did not exceed $10 \%$ of all plants studied. This should be taken into account while creating fertile lines, especially the ones responsible for sterility fixation since it requires monogerm plants.

\section{Conclusions}

Obtaining self-fertilizing constant lines for table beet heterosis breeding is a complex process, because the self-incompatibility attribute is under gametophytic control, and its manifestation degrees vary significantly in plants from inbred progenies. In case of self-pollination, the reproductive ability of table beet plants also depends on the inbreeding depression level, which affects microgametophytic functional parameters and seed embryo development.

The use of recurrent breeding based on seed productivity, pollen tube length, and field germination rate increases the yield of forms with potentially high self-compatibility in the progeny. To ensure reproduction and preservation of the valuable linear material, one should perform sib crossings not later than the third or earlier inbred generations from promising inbred progenies by selecting the mf-forms most prone to self-fertilization.

\section{References}

Arkhipov M.V., Alekseeva D.I., Batygin N.F., Velikanov L.P., Gusakova L.P., Derunov I.V., Zheludkov A.G., Nikolenko V.F., Nikitina L.I., Savin V.N., Ponomarenko E.N., Yakushev V.P. X-ray Technique in Agriculture and Crop Production. Moscow, 2001. (in Russian)

Balkov I.J. Sugar Beet Selection for Heterosis. Moscow, 1978. (in Russian)

Burenin V.I. The use of inbreeding in beet. Sakharnaya Svekla = Sugar Beet. 2015;1:11-14. (in Russian)

Burenin V.I., Pivovarov V.F. Beta Vulgaris. St. Petersburg, 1998. (in Russian)

Chantha S.C., Herman A.C., Platts A.E., Vekemans X., Schoen D.J. Secondary evolution of a self-incompatibility locus in the Brassicaceae genus Leavenworthia. PLoS Biol. 2013;11(5). DOI 10.137/journal.pbio.1001560.

Chen Q. Meng D., Gu Z., Li W., Yuan H., Duan X., Yang Q., Li Y., Li T. SLFL genes participate in the ubiquitination and degradation reaction of S-RNase in self-compatible peach. Front. Plant Sci. 2018; 9:227. DOI 10.3389/fpls.2018.00227.

Darmency H., Klein E.K., De Garanbe T.G., Gouyon P.H., Richard-Molard M., Muchembled C. Pollen dispersal in sugar beet production fields. Theor. Appl. Genet. 2009;118(6):10831092. DOI 10.1007/s00122-009-0964-y.

Entani T., Iwano M., Shiba H., Che F.S., Isogai A., Takayama S. Comparative analysis of the self-incompatibility $(S$-) locus region of Prunus mume: identification of a pollen-expressed F-box gene with allelic diversity. Genes Cells. 2003;8(3):203213. DOI 10.1046/j. 1365-2443.2003.00626.x.

Escribano J., Pedreño M.A., García-Carmona F., Muñoz R. Characterization of the antiradical activity of betalains from Beta vulgaris L. roots. Phytochem. Anal. 1998;9(3):124-127. DOI 10.1002/(SICI)1099-1565(199805/06)9:3<124::AIDPCA401>3.0.CO;2-0. 
Fedorova M.I., Burenin V.I. Biology, genetics, and breeding of table beet. In: Maletsky S.I. (Ed.). Encyclopedia of the Genus Beta: Biology, Genetics and Breeding of Sugar Beet. Novosibirsk: Sova Publ., 2010;588-597. (in Russian)

Fedorova M.I., Stepanov V.A. The main directions and methods of breeding of root plants. In: Breeding and Seed Production of Root Vegetable Crops. Moscow, 2005;13-17. (in Russian)

Fedorova M.I., Vetrova S.A., Kozar E.G. Features of the phenotypic manifestation of the CMS symptom in beetroot seed plants. Ovoshchi Rossii $=$ Vegetable Crops of Russia . 2011;3(12);18-23. (in Russian)

Foote H.C., Ride J.P., Franklin-Tong V.E., Walker E.A., Lawrence M.J., Franklin F.C. Cloning and expression of a distinctive class of self-incompatibility $(S)$ gene from Papaver rhoeas L. Proc. Natl. Acad. Sci. USA. 1994;91(6):22652269. DOI 10.1073./pnas.91.6.2265.

Knox R.B., Heslop-Harrison J. Pollen wall proteins: localization and enzymatic activity. J. Cell Sci. 1970;6:1-27.

Konovalov A.A., Maletsky S.I. Segregation for S loci during inbreeding in sugar beet. Genetika= Genetics. 1990;26(8):14401447. (in Russian)

Korneeva M.A., Golichenko T.V. Seed Productivity in SelfPollination of Sugar Beet Plants in Greenhouses and Fields. Methods of increasing the productivity of sugar beet and seed plants. Kiev, 1989. (in Russian)

Korneeva M.A., Vlasyuk N.V. The effect of inbreeding on the quality of pollen from sugar beet pollinators of varying degrees of heterozygosity. In: Current Issues in Genetics. 2003;1:106-107. (in Russian)

Kozar E.G., Fedorova M.I., Vetrova S.A., Zayachkovsky V.A., Stepanov V.A. Assessment of Functional Parameters of Microgametophytes of Inbred Beetroot Plants. Moscow, 2017. (in Russian)

Krasochkin V.T. Root crops. In: Cultural Flora of the USSR. Vol. 19. Leningrad, 1971. (in Russian)

Kubo K.I., Entani T., Takara A., Wang N., Fields A.M., Hua Z., Toyoda M., Kawashima S.-I., Ando T., Isogai A. Collaborative non-self recognition system in S-RNase-based selfincompatibility. Science. 2010;330(6005):796-799. DOI 10.1126/science. 1195243.

Lapin A.A., Bykovsky D.V., Davydov U.A., Zelenkov V.N. Beet juice is a source of antioxidants. Kartofel i Ovoshchi $=$ Potatoes and Vegetables. 2007;6:27. (in Russian)

Lewis D., Crowe L.K. Unilateral interspecific incompatibility in flowering plants. Heredity. 1958;2:233-256. DOI 10.1038/ hdy.1958.26.

Logvinov V.A., Krasilnikov E.A., Volgin V.V., Logvinova A.P., Kudryavtseva N.V. Self-compatibility of sugar beet in the process of inbreeding. Selskokhozyaystvennaya Biologiya $=$ Agricultural Biology. 1993;3:22-25. (in Russian)

Lundqvist A., Osterbye V., Larsen K., Ib Linde Laursen. Complex self-incompatibility systems in Ranunculus acris L. and Beta vulgaris L. Hereditas. 1973;74:161-168.

Lyalko I.I., Sidorenko A.S., Shevtsov I.A. Raise of sterility fixers for heterosis selection of sugar beet. Vestnik Agrarnoy Nauki $=$ Bulletin of Agrarian Science. 1997;10:52-54. (in Russian)

Mabry T.J. Betalains. In: Bell E.A., Charlwood B.V. (Eds.). Encyclopedia of Plant Physiology (Secondary Plant Prod- ucts). Vol. 8. Berlin; Heidelberg; New York: Springer-Verlag, 1980;513-533.

Magassy I. Recent experimental results on self-incompatibility and self-compatibility in beet (Beta vulgaris). Acta Agron. J. 1965;13(3/4): 241-262.

Maletsky S.I. Variation of cytoplasmically controlled sterility in sugar beet (Beta vulgaris L.) pollen and its relationship with mitochondrial heteroplasmy in cells. Genetika $=$ Genetics. 1995;31(11): 1461-1467. (in Russian)

Maletsky S.I. (Ed.). Encyclopedia of the Genus Beta: Biology, Genetics and Breeding of Sugar Beet. Novosibirsk: Sova Publ., 2010;542-554. (in Russian)

Maletsky S.I., Denisova E.V., Lutkov A.N. Raise of self-pollinated lines from self-incompatible sugar beet plants. Genetika $=$ Genetics. 1970;6(6):180. (in Russian)

Musaev F.B., Arkhipov M.V., Priyatkin N.S., Staroverov I.E., Potrakhov N.N. The microfocal radiography method for analyzing the quality of vegetable seeds. In: Trends in the Development of Agrophysics: from Topical Issues of Agriculture and Crop Production to Future Technologies: Proceedings of the Int. Sci. Conf. dedicated to the 85th anniversary of the Agrophysical Research Institute. Moscow, 2017a;332-336. (in Russian)

Musayev F.B., Bukharov A.F., Kozar E.G., Beletsky S.L. A modern instrumental method of seed quality control. Ovoshchi Rossii $=$ Vegetable Crops of Russia. 2017b;4(37):7377. DOI 10.18619/2072-9146-2017-4-73-77. (in Russian)

Musaev F.B., Prozorova O.A., Arkhipov M.V., Velikanov L.P., Potrakhov E.N., Bessonov V.B. X-ray analysis of the quality of vegetable seeds. Ovoshchi Rossii = Vegetable Crops of Russia. 2012; 4(17):43-47. (in Russian)

Oshevnev V.P., Gribanova N.P. Breeding of self-compatible Otype pollinators in sugar beet. In: Maletsky S.I. (Ed.). Encyclopedia of the Genus Beta: Biology, Genetics and Breeding of Sugar Beet. Novosibirsk: Sova Publ., 2010;542-554. (in Russian)

Owen F.V. Intheritance of cross- and self-sterility and self-fertility in Beta vulgaris L. J. Agric. Res. 1942;64:679-698.

Pialetti M. Betalains. Chemistry and Biochemistry of Plant Pigments. New York: Acad. Press, 1976;1:560.

Ramanauskas K., Igić B. The evolutionary history of plant T2/S-type ribonucleases. Peer J. 2017;5:3790. DOI 10.7717/ peerj.3790.

Sleptsov I.V., Voronov I.V., Zhuravskaya E.R., Poskachina E.R. Isolation and identification of betacyanin pigments from Beta vulgaris and Amaranthus ratroflexus. Khimiya Rastitelnogo Syrya $=$ Chemistry of Plant Materials. 2015;3:111-115. DOI 10.14258/jcprm. 201503757. (in Russian)

Tesoriere L., Allegra M., Butera D., Livrea M.A. Absorption, excretion, and distribution of dietary antioxidant betalains in LDLs: potential health effects of betalains in humans. Am. J. Clin. Nutr. 2004; 80(4):941-945. DOI 10.1093/ajcn/80.4.941.

Vavilov N.I. Botanical and Geographical Basis of Breeding. In: Theoretical Bases of Selection. Vol. 1. Moscow; Leningrad, 1935. (in Russian)

Yamane H., Ikeda K., Ushijima K., Sassa H., Tao R. A pollenexpressed gene for a novel protein with an F-box motif that is very tightly linked to a gene for S-RNase in two species of cherry, Prunus cerasus and P. avium. Plant Cell Physiol. 2003;44(7):764-769. DOI 10.1093/pcp/pcg088. 
Zayachkovsky V.A., Startsev V.I., Balashova N.N. Development of elements of heterosis-assisted breeding of beetroot. Gavrish. 1999;3:24-25. (in Russian)

Zhuzhzhalova T.P. The effect of inbreeding on the formation of generative organs in sugar beet. In: Maletsky S.I. (Ed.). Encyclopedia of the Genus Beta: Biology, Genetics, and Breed- ing of Sugar Beet. Novosibirsk: Sova Publ., 2010;164-189. (in Russian)

Zhuzhzhalova T.P., Znamenskaya V.V., Podvigina O.A., Yarmolyuk G.I. Reproductive Biology of Sugar Beet. Voronezh, 2007. (in Russian)

\section{ORCID ID}

M.I. Fedorova orcid.org/0000-0002-7533-5185

E.G. Kozar orcid.org/0000-0002-1319-5631

S.A. Vetrova orcid.org/0000-0002-9897-0413

V.A. Zayachkovskyi orcid.org/0000-0001-9821-5381

Conflict of interest. The authors declare no conflict of interest.

Received September 21, 2018. Revised March 21, 2019. Accepted March 22, 2019. 